\title{
Predicting Soluble Nitrogen and Fibrous Fractions in Crested Wheatgrass with Near- Infrared-Reflectance Spectroscopy
}

\author{
Y.W. PARK, M.J. ANDERSON, K.H. ASAY, AND A.W. MAHONEY
}

\section{Abstract}

A near-infrared-reflectance (IR) spectroscopic method was evaluated for potential usage in predicting soluble $\mathrm{N}$, total $\mathrm{N}$ and some fibrous fractions in crested wheatgrass, Agropyron cristatum (L.) Gaertn., A. desertorum (Fisch. ex Link), et al.

The correlation coefficients $(r)$ between IR and total $N$, soluble $\mathrm{N}$ in $0.15 \mathrm{~N} \mathrm{NaCl}$ (N Sal), soluble $\mathrm{N}$ in $10 \%$ Burroughs Mineral Mixture solution (NBMM), neutral detergent fiber (NDF), acid detergent fiber (ADF), and acid detergent lignin (ADL) for 84 samples were $0.95,0.90,0.70,0.90,0.82$, and 0.72 , respectively. The IR technique provided a closer estimation of total $\mathbf{N}$ and $\mathbf{N}$ Sal than of NBMM in the calibration data. The mean solubility of $N$ Sal was higher than that of NBMM. High variation occurred between the duplicate determinations of NBMM. The predictions on 30 unknown samples by the equation developed using 84 calibration samples for mean, SED (standard error of difference), and $r$ were: total $\mathrm{N}, 1.01,0.04,0.98 ; \mathrm{N}$ Sal, $0.43,0.04,0.90 ; \mathrm{NDF}, 64.1$, $0.96,0.93, A D F, 36.2,1.01,0.91$; and ADL, 5.24, 0.53, 0.62. Predictions of fibrous fractions were highly satisfactory even though the correlations were low.

Correlations between chemical determinations of total $\mathbf{N}$ and $\mathbf{N}$ Sal, NBMM, NDF, ADF, ADL were $0.89,0.53,-0.13,-0.33$, $\mathbf{- 0 . 0 8}$, respectively. Significant differences $(P<0.01)$ were found among crested wheatgrass species for all nitrogenous and fibrous fractions measured. Differences among clonal lines within species were also significant $(P<0.05$ or 0.01$)$ for all determinations indicating that opportunities are available to improve the nutritional value of crested wheatgrass through selection.

Physical properties of proteins in feeds may be indicative of their feeding values for ruminants (Little et al. 1963). Soluble nitrogen in purified proteins is positively correlated with the degradation of nitrogenous material in the rumen (Blackburn 1965, Henderickx and Martin 1963).

Recently developed near-infrared-reflectance (IR) techniques have been used to determine moisture content in grains and seeds (Norris and Hart 1965, Ben Gera and Norris 1968); crude protein (CP) and oil concentration in soybeans, corn and oats (Hymowitz et al. 1974, Rinne et al. 1975); total reducing sugars in tobacco (McClure et al. 1976) nutritve qualities of forages (Norris et al. 1976, Shenk et al. 1979); and neutral detergent fiber (NDF) in breakfast cereal (Baker et al. 1979).

Norris et al. (1976) reported correlation coefficients $(r)$ between chemical determinations and IR predicted values of 0.99 for $C P$,

Authors are postdoctoral research associate, Department of Nutrition and Food Sciences, Utah State Uni versity, Logan 84322; research animal scientist, USDA-ARS, Logan 84322; research geneticist, USDA-ARS, Logan 84322; and professor, Department of Nutrition and Food Sciences, Utah State University.

Research involved cooperative investigations of the USDA-ARS and Department of Animal, Dairy and Veterinary Sciences, Utah State University, Logan, Utah 84322. This report is approved as Utah Agricultural Experiment Station Journal Paper No. 2761 .

The authors wish to thank Dr. J.L. Walters for his assistance in statistical analysis and to Dr. P.V. Fonnesbeck for the use of his laboratory facilities for the chemical analysis.

Manuscript received February 1, 1982.
0.98 for NDF, 0.96 for acid detergent fiber (ADF), 0.96 for lignin, 0.95 for in vit ro dry matter disappearance, and 0.88 for $\mathrm{dry}$ matter digestibility determined in vivo.

The percentages of soluble $\mathrm{N}$ in most forages exist in relatively minute quantities. The feasibility of using IR instrumentation to estimate soluble $\mathbf{N}$ in forages has not been studied to date. The application of IR in predicting fibrous fractions in crested wheatgrass Agropyron cristatum (L.) Gaertn, A. desertorum (Fisch. ex Link) et al. also is untested. The objectives of this study were: (1) to determine the correlation between IR predicted values and chemical determinations of total $\mathbf{N}$, soluble $\mathbf{N}$, and fibrous fractions (NDF, ADF, and ADL) in crested wheatgrass; and (2) to estimate the amount of genetic variability in a crested wheatgrass breeding population for chemical and physical entities measured under objective 1 .

\section{Materials and Methods}

\section{Field Plots and Sample Preparation}

Seven clonal lines from each of six sources of crested wheatgrass (1) A. Sibiricum (Willd.) Beauv.; (2) A. cristatum var. 'Fairway'; (3) A. cristatum, induced tetraploid (128); (4) A. cristatum, collected from Iran by D.R. Dewey (Dewey and Asay, 1975); (5) $A$. desertorum; and (6) the $A$. cristatum (128) $\times A$. desertorum hybrid we included in the study. The field design was a randomized complete block with two replications. Individual plots consisted of two plants which were established from vegetative propagules on $0.5 \times 0.9 \mathrm{~m}$ spacings on April 6, 1977.

The soil was a member of the fine-silty, mesic family of calcic argiherolls. Annual precipitation was $380-430 \mathrm{~mm}$ (15-17 in.). In September $1978,56 \mathrm{~kg} /$ ha of $\mathrm{N}$ fertilizer was applied. The forage was harvested July 3 and 5, 1979, and air dired in a greenhouse at about $38^{\circ} \mathrm{C}$. Samples for analyses consisted of a composite of the two plants in a plot. After drying, the samples were ground first in a Wiley mill' (1-mm screen), then in a cyclone mill, and stored in plastic bags. Duplicate chemical determinations were subsequently made on each sample.

\section{Chemical Analysis of Soluble $\mathbf{N}$}

A modified method of the Crooker et al. (1978) procedure was used for soluble $\mathrm{N}$ analysis. A $2.5 \mathrm{~g}$ sample containing about $50 \mathrm{mg}$ of nitrogen and $100 \mathrm{ml}$ of solvent preheated to $40^{\circ} \mathrm{C}$ was poured into a $250 \mathrm{ml}$ screw cap polycarbonate Erlenmeyer flask (Corning No. 25600) and the flask was placed in an electric shaker (Eberbach, Ann Arbor, Mich.). After 2-hours incubation in a constanttemperature mechanical shaker at $40^{\circ} \mathrm{C}$, the sample-solvent suspension was filtered through filter paper (Van Walters \& Rogers, White, Crepe $11 \mathrm{~cm}$ ), placed in a Fisher Filtrator funnel (Coors, U.S.A.) with a water aspirator system. fifty $\mathrm{ml}$ of the filtered extraction was put in a $50-\mathrm{ml}$ plastic centrifuge tube and centrifuged at $1400 \times \mathrm{g}$ for 15 minutes. The $50 \mathrm{ml}$ of filtrate was

\footnotetext{
Mention of brand names does not constitute endorsement by Utah State University nor the U.S. Department of Agriculture in favor of other products that are equally
} suitable. 
decanted into a Kjeldahl flask for macro-Kjeldahl determination for total soluble $\mathbf{N}$.

$\mathrm{NaCl}$ Solution $(\mathrm{J}=0.15)$

Sodium chloride solution with an ionic strength (j) of $0.15(0.15$ N) was made by dissolving $87.66 \mathrm{~g} \mathrm{NaCl}$ in 10 liters of distilled water. The final $\mathrm{pH}$ of the solution was 6.3

10\% Burrough Mineral Mixture Solution $(J=2.11)$

Burroughs mineral mixture (BMM) was formulated from 12 mineral salts according to Burroughs (1950).

Salts go into solution easier if added in the specific order described by Crooker et al. (1978). After the addition of $\mathrm{CaCl}_{2} .2 \mathrm{H}_{2} \mathrm{O}$, $\mathrm{CO}_{2}$ was introduced by putting dry ice in the solution until it became clear. If necessary, $\left(\mathrm{NH}_{4}\right)_{2} \mathrm{SO}_{4}$ can be replaced by $\mathrm{Na}_{2} \mathrm{SO}_{4}$ on an equimolar basis $(20.155 \mathrm{~g})$ for modified Burroughs mineral moisture solution. When all salts were dissolved, the solvent was adjusted to pH 6.5 with 85\% ortho-phosphoric acid.

\section{Fiber Analyses}

Percent neutral detergent fiber (NDF) was determined by using the procedures of Van Soest and Wine (1967) and Goering and Van Soest (1970). Percent acid detergent fiber (ADF) and acid detergent lignin (ADL) were determined by the method of Van Soest (1963), in which the ADF measurement is the major preparatory step for $\mathrm{ADL}$ determination.

\section{Statistical Analyses}

Analyses of variance were computed as a randomized complete block with clonal lines nested within species. Species and clones within species were considered as fixed and replications as random effects. Therefore, any interpretations of the data should be limited to the crested wheatgrass populations studied herein.

\section{Infrared Reflectance Analysis and Instrumentation}

The instrument used was a Neotec 6100 prism-grating monochromator interfaced to a Digital computer (PDP-1103)'. The dry granular samples were packed in a sample holder covered with an infrared transmitting quartz window and illuminated with the monochromatic radiation that was diffusely reflected through the quartz window for about 1 minute. The reflectance curves were detected by lead-sulfide cell detectors equally spaced around the incident beam. The signal from the detectors was amplified with a logarithmic-response amplifier, digitized and fed to the digital computer. The wavelength range from 1100 to $2500 \mathrm{~nm}$ was scanned at every $2 \mathrm{~nm}$ width of the reflectance curve. All reflectance readings were referenced to a ceramic standard that had been characterized by the National Bureau of Standards for reflectance in the near-infrared region. The spectral reflectance $(R)$ curves were recorded as the second derivative of the original $\log (1 / R)$ absorption curve because it has generally given the highest correlation for the relative chemical composition (Norris et al. 1976).

The chemical analysis and spectral data were subjected to a stepwise multiple-linear regression analysis to determine to optimum wavelengths for prediction equations. The computer was programmed to predict IR values based on spectral data and subsequently to give the correlation $(r)$ between the 2 methods of measuring the variables.

\section{Results and Discussion}

\section{Chemical Data}

\section{Nitrogenous Fractions}

Significant differences were found among the crested wheatgrass species in concentrations of total $\mathrm{N}$ and both soluble fractions (Tables 1 and 2). Total $\mathrm{N}$ ranged from 0.94 to $1.12 \%$, which is equivalent to 5.88 to $7.00 \%$ total protein. The cultivar, Fairway, had the highest total $\mathrm{N}$ and soluble $\mathrm{N}$ in $\mathrm{NaCl}$ (N Sal) and the induced tetraploid (128), A. cristatum had the lowest total N and N Sal contents. This is not surprising as Fairway is leafier than the other entries. On the other hand, the induced tetraploid is more robust and somewhat coarser than its Fairway progenitor.

The clone within species source of variation was also significant for total $\mathrm{N}$ and soluble $\mathrm{N}$ components. From a plant breeding point of view, this is encouraging because it indicates that genetic variability is a vailable for selection purposes. Additional data involving more environments (years, locations, and management systems) would be needed to verify this point, however.

There was a significant correlation $\left(r=0.89^{* *}\right)$ between total $\mathrm{N}$ and N Sal, but a comparatively low correlation $\left(r=0.53^{* *}\right)$ between total $\mathrm{N}$ and soluble $\mathrm{N}$ in BMM (NBMM) (Table 3 ). The correlation between the two soluble $\mathrm{N}$ fractions was $0.65^{* *}$. Substantial differ-

Table 1. Nitrogenous and fibrous fractions in the forage of 6 crested wheatgrass species.

\begin{tabular}{|c|c|c|c|c|c|c|}
\hline \multirow[b]{3}{*}{ Species } & \multicolumn{3}{|c|}{ Nitrogenous fraction } & \multirow{2}{*}{\multicolumn{3}{|c|}{ Fibrous fraction }} \\
\hline & \multirow{2}{*}{$\begin{array}{c}\text { Total } \\
\mathbf{N}\end{array}$} & \multicolumn{2}{|c|}{ Soluble N } & & & \\
\hline & & $\mathrm{NaCl}$ & BMM & DFF & \multirow[t]{2}{*}{ ADF } & \multirow[t]{2}{*}{ ADL } \\
\hline & & & & $\%-$ & & \\
\hline A. sibricun & & & & & & \\
\hline $\begin{array}{l}\text { Range } \\
\text { Mean }\end{array}$ & $\begin{array}{l}1.04-1.56 \\
1.11\end{array}$ & $\begin{array}{l}0.39-0.54 \\
0.41\end{array}$ & $\begin{array}{l}0.31-0.57 \\
0.38\end{array}$ & $\begin{array}{l}62.1-68.3 \\
64.4\end{array}$ & $\begin{array}{l}32.5-39.4 \\
37.1\end{array}$ & $\begin{array}{l}4.83-6.50 \\
5.57\end{array}$ \\
\hline $\begin{array}{l}\text { A. cris. (Fa } \\
\text { Range } \\
\text { Mean }\end{array}$ & $\begin{array}{l}0.95-1.61 \\
1.12\end{array}$ & $\begin{array}{l}0.31-0.64 \\
0.44\end{array}$ & $\begin{array}{l}0.19-0.63 \\
0.34\end{array}$ & $\begin{array}{l}60.1-66.1 \\
62.8\end{array}$ & $\begin{array}{l}32.0-36.3 \\
34.3\end{array}$ & $\begin{array}{l}3.88-5.65 \\
5.19\end{array}$ \\
\hline $\begin{array}{l}\text { A. cris. (12 } \\
\text { Range } \\
\text { Mean }\end{array}$ & $\begin{array}{l}0.85-1.10 \\
0.94\end{array}$ & $\begin{array}{l}0.29-0.42 \\
0.35\end{array}$ & $\begin{array}{l}0.17-0.36 \\
0.27\end{array}$ & $\begin{array}{l}60.5-65.1 \\
63.8\end{array}$ & $\begin{array}{l}33.6-36.8 \\
35.4\end{array}$ & $\begin{array}{l}3.86-5.62 \\
4.88\end{array}$ \\
\hline $\begin{array}{l}\text { A. cris. (Ira } \\
\text { Range } \\
\text { Mean }\end{array}$ & $\begin{array}{l}0.96-1.39 \\
1.10\end{array}$ & $\begin{array}{l}0.34-0.47 \\
0.39\end{array}$ & $\begin{array}{l}0.19-0.47 \\
0.32\end{array}$ & $\begin{array}{l}57.1-67.2 \\
63.6\end{array}$ & $\begin{array}{l}36.8-41.67 \\
38.4\end{array}$ & $\begin{array}{l}4.81-7.26 \\
5.99\end{array}$ \\
\hline $\begin{array}{l}\text { A. desertor } \\
\text { Range } \\
\text { Mean }\end{array}$ & $\begin{array}{l}0.86-1.29 \\
1.00\end{array}$ & $\begin{array}{l}0.28-0.41 \\
0.39\end{array}$ & $\begin{array}{l}0.19-0.41 \\
0.32\end{array}$ & $\begin{array}{l}59.4-67.9 \\
64.9\end{array}$ & $\begin{array}{l}32.440 .6 \\
37.2\end{array}$ & $\begin{array}{l}4.49-6.57 \\
5.29\end{array}$ \\
\hline $\begin{array}{l}\text { A. cris. (12 } \\
\text { Range } \\
\text { Mean }\end{array}$ & $\begin{array}{l}0.98-1.40 \\
0.99\end{array}$ & $\begin{array}{l}0.32-0.51 \\
0.37\end{array}$ & $\begin{array}{l}0.26-0.43 \\
0.28\end{array}$ & $\begin{array}{l}56.1-65.7 \\
64.0\end{array}$ & $\begin{array}{l}31.1-37.9 \\
35.8\end{array}$ & $\begin{array}{l}4.08-6.20 \\
4.96\end{array}$ \\
\hline $\operatorname{LSD}(.05)$ & 0.08 & 0.05 & 0.05 & 1.29 & 1.06 & 0.28 \\
\hline
\end{tabular}


Table 2. Mean squares from analyses for variance of chemical determinations of forage quality in crested wheatgrass.

\begin{tabular}{|c|c|c|c|c|c|c|c|}
\hline \multirow[b]{3}{*}{ Source } & \multirow[b]{3}{*}{ df } & \multicolumn{3}{|c|}{ Nitrogenous fraction } & & & \\
\hline & & \multirow{2}{*}{$\begin{array}{c}\text { Total } \\
\mathbf{N}\end{array}$} & \multicolumn{2}{|c|}{ Soluble N } & \multicolumn{3}{|c|}{ Fibrous fraction } \\
\hline & & & $\mathrm{NaCl}$ & BMM & NDF & ADF & ADL \\
\hline $\begin{array}{l}\text { Species } \\
\text { Clones/sp } \\
\text { Pooled error }\end{array}$ & $\begin{array}{r}5 \\
36 \\
41\end{array}$ & $\begin{array}{l}0.085^{* *} \\
0.032^{* *} \\
0.011\end{array}$ & $\begin{array}{l}0.015 * \\
0.0062^{*} \\
0.0032\end{array}$ & $\begin{array}{l}0.025^{* *} \\
0.013^{* *} \\
0.0041\end{array}$ & $\begin{array}{l}7.40^{\star} \\
1.35^{\star} \\
2.76\end{array}$ & $\begin{array}{l}30.3^{* *} \\
9.62^{* *} \\
1.85\end{array}$ & $\begin{array}{l}2.37^{* *} \\
1.14^{* *} \\
0.129\end{array}$ \\
\hline
\end{tabular}

*** Significant at 0.05 and 0.01 levels of probability, respectively.

ences existed in the solubility of $\mathbf{N}$ in the two solvents. The nitrogen extracted from feedstuffs with salt solutions can be divided into protein nitrogen and nonprotein nitrogen (NPN) fractions. The NPN usually is characterized as free amino acids, nitrates, ammonia, and urea in some feedstuffs (Crooker et al. 1978). Solubility for the protein and nonprotein fractions in crested wheatgrass could differ between the two solvents. Although most nonprotein nitrogen sources in feedstuffs are readily soluble, solubility of the protein fraction is affected by several factors. These include degree of agitation, length of extraction time, temperature of extraction, $\mathrm{pH}$, chemical composition, and ionic st rength of the solvent (Lehninger 1970). The BMM solution is a mixture of at least 12 different minerals some of which could interfere with solubility of $\mathrm{N}$ compounds, whereas the $0.15 \mathrm{~N} \mathrm{NaCl}$ solution is isotonic with body fluid and has less minerals to interfere with solubility of $\mathbf{N}$ compounds.

\section{Fibrous fractions}

Differences among species means were significant for ADF ( $P<0.01)$, ADL $(P<0.01)$. and NDF $(P<0.05)$ (Table 2). Clones within species differed significantly $(P<0.01)$ in all three instances, suggesting again that genetic variability is available for improving the forage quality of crested wheatgrass.

Total $\mathbf{N}$ and soluble $\mathbf{N}$ were negatively correlated with NDF, $A D F$, and $A D L$ (Table 3). The correlations among the nitrogenous fractions were positive and significant. The positive and significant correlations between NDF and ADF $(r=0.55)$ and between ADF and ADL ( $r=0.53$ ) were probably associated with common variables as cellulose, hemicellulose, and lignin. The low correlation between NDF and ADL $(r=0.20)$ confirmed that NDF was not as closely related to $\mathrm{ADL}$ as was $\mathrm{ADF}$.

\section{IR Predictions and Correlations \\ Nitrogenous Fractions}

The respective correlations between IR and chemically determined values for total $N$ of the 84 calibration samples and the 30 unknowns using 3 wavelengths were 0.95 and 0.98 (Table 4 and 5). The IR predictions on the unknowns gave even more precise estimations of total $\mathbf{N}$ than were obtained for the 84 samples. The high correlations agree with protein values reported by several workers (Hymowitz et al. 1974; Norris et al. 1976; Shenk et al. 1979). The failure of the correlation to improve from 3 to 8 wavelengths indicated that the use of more than 3 wavelengths for protein would not be warranted. Shenk et al. (1977) suggested that the use of too many or too few wavelengths would produce an overfit of the prediction equation resulting in a high standard error prediction (SEP) in the calibration equation.

The correlation $(r=0.90)$ for N Sal using 5 wavelengths was substantially higher than for NBMM $(r=0.70)$. The predicted

Table 3. Correlations ( $r$ ) among chemical determinations of forage quality in crested wheatgrass.

\begin{tabular}{lcccccc}
\hline & \multicolumn{2}{c}{ Soluble N } & & & \\
& & & & & \\
& $\mathrm{NaCl}$ & $\mathrm{BMM}$ & $\mathrm{NDF}$ & $\mathrm{ADF}$ & $\mathrm{ADL}$ \\
\cline { 2 - 6 } & $0.89^{* * 1}$ & $0.53^{* *}$ & -0.13 & $-0.33^{* *}$ & -0.08 \\
Total N & & & & & \\
Soluble N & & $0.65^{* *}$ & -0.01 & $-0.25^{*}$ & -0.02 \\
$\mathrm{NaCl}$ & & & $0.34^{* *}$ & 0.15 & -0.11 \\
$\mathrm{BMM}$ & & & & $0.55^{* *}$ & 0.20 \\
$\mathrm{NDF}$ & & & & & $0.53^{* *}$ \\
$\mathrm{ADF}$ & & & & &
\end{tabular}

means and SEDs were 0.39 and 0.032 for $N$ Sal and 0.32 and 0.066 for NBMM (Table 4). The prediction of $\mathrm{N}$ Sal in the unknown samples was satisfactory and was similar to the calibration data $(r=0.90)$. On the other hand, there was too much variation between the duplicate determinations of NBMM. This variation contributed to the low $r$ value. Therefore, the prediction of NBMM would not be reliable and was not tested against unknowns.

Crooker et al. (1978) detected several feed-solvent interactions during soluble $\mathbf{N}$ extractions showing that ionic species contained the solvent affected the nitrogen extractions. The $0.15 \mathrm{~N} \mathrm{NaCl}$ solution is much less complex in terms of ionic species than the $10 \%$ BMM solution. Crooker et al. (1978), comparing the correlations between soluble $\mathrm{N}$ in 3 mineral solvents $[\mathrm{NaCl}, \mathrm{BMM}$, and

Table 4. Comparison of actual versus IR predicted values of total N, soluble N, NDF, ADF, and ADL for the 84 crested wheatgrass, calibration samples.

\begin{tabular}{|c|c|c|c|c|c|c|c|c|c|c|c|c|}
\hline \multirow[b]{4}{*}{$\begin{array}{l}\text { No. of wavelengths } \\
\text { Mean }(\%)\end{array}$} & \multicolumn{6}{|c|}{ Nitrogenous fraction } & \multirow{2}{*}{\multicolumn{6}{|c|}{ Fibrous fraction }} \\
\hline & \multirow{2}{*}{\multicolumn{2}{|c|}{ Total N }} & \multirow{2}{*}{\multicolumn{2}{|c|}{$\begin{array}{l}\text { Soluble } \mathbf{N} \\
\text { in } \mathrm{NaCl}\end{array}$}} & \multirow{2}{*}{\multicolumn{2}{|c|}{$\begin{array}{l}\text { Soluble } \mathbf{N} \\
\text { in BMM }\end{array}$}} & & & & & & \\
\hline & & & & & & & \multicolumn{2}{|l|}{ NDF } & \multicolumn{3}{|c|}{ ADF } & \multirow{2}{*}{$\frac{\mathrm{ADL}}{\sigma}$} \\
\hline & 2 & 3 & 5 & 8 & 5 & 8 & 5 & 8 & 5 & 8 & 5 & \\
\hline Chemical & 1.05 & 1.05 & 0.39 & 0.39 & 0.32 & 0.32 & 63.8 & 63.8 & 36.3 & 36.3 & 5.31 & 5.31 \\
\hline IR Predicted & 1.05 & 1.05 & 0.39 & 0.39 & 0.32 & 0.32 & 63.8 & 63.8 & 36.3 & 36.3 & 5.31 & 5.31 \\
\hline \multicolumn{13}{|l|}{ SD } \\
\hline Chemical & 0.173 & 0.173 & 0.073 & 0.073 & 0.097 & 0.097 & 2.91 & 2.91 & 2.70 & 2.70 & 0.85 & 0.85 \\
\hline IR Predicted & 0.158 & 0.164 & 0.065 & 0.067 & 0.067 & 0.069 & 2.60 & 2.69 & 2.21 & 2.35 & 0.60 & 0.63 \\
\hline SED & 0.070 & 0.055 & 0.032 & 0.028 & 0.068 & 0.066 & 1.29 & 1.09 & 1.52 & 1.30 & 0.58 & 0.54 \\
\hline$r$ & 0.91 & 0.95 & 0.90 & 0.93 & 0.70 & 0.73 & 0.90 & 0.93 & 0.82 & 0.88 & 0.72 & 0.76 \\
\hline
\end{tabular}

SD Standard deviation

SED Standard error of difference in residual values between chemical and IR predicted value.

$r$ Correlation coefficient. 
matter and nonprotein alcohol insoluble matter. Van Soest and Marcus (1964) have also observed distinct differences of fiber digestibility between grasses and legumes. They included empirical fiber fractions of hemicellulose, cellulose, NDF, ADF, crude fiber. It is suggested that chemical and digestibility differences between grasses and legumes are great enough to significantly reduce the accuracy of equations for predicting forage digestibility with a single IR equation.

The predictability of NDF in the unknown samples was highest among the three fibrous fractions. It was interesting that the $r$ values for the unknown samples were continuously increased from 0.88 to 0.96 as the number of wavelength s were increa sed to 8 . This outcome indicates that the use of higher numbers of wavelengths may not create an over-fitting effect in certain cases, which is in contrast to the report of Shenk et al. (1977).

Goering and Van Soest (1970) suggested that the neutral detergent procedure for cell walls can divide the dry matter of feeds nea $r$ the point that separates the nutritively available and soluble constituents from those which are incompletely available or dependent on microbial fermentation. Hence the IR predictions of NDF in crested wheatgrass have a good potential for estimating nutritive value. When unknown samples having chemical values that were markedly different from IR predicted ones were re-analyzed, the newly determined values were much closer to the predicted ones, as seen in the case of $\mathbf{N}$ Sal.

\section{Literature Cited}

Baker, D., K.H. Norris, and B.W. Li. 1979. Food analysis: Advances in Methodology. In: Dietary fibers; chemistry and nutrition. (Ed) G.E. Inglett \& S.I. Falkehag. Academic Press. New York. 1979.

Ben Gera, I., and K.H. Norris. 1968. Determination of moisture content in soybeans by direct spectrophotometry. Israel J. Res. 18:125.

Blackburn, T.H. 1965. Nitrogen metabolism in the rumen. In: Physiology of digestion in the ruminant. (Ed.) R.W. Dougherty. Butterworth, Inc., Washington, D.C.

Burroughs, W., N.A. Frank, P. Gerlaugh, and R.M. Bethke. 1950. Preliminary observations upon factors influencing cellulose digestion by rumen microorganisms. J. Nutr. 40:9.

Crooker, B.A., C.J. Sniffen, W.J. Hoover, and L.L. Johnson. 1978. Solvents for soluble nitrogen measurements in feedstuffs. J. Dairy Sci. 61:437-447.
Goering, H.K., and P.J. Van Soest. 1970. Forage fiber analyses. Apparatus, reagents, procedures, and some application. ARS. Agr. Handbook No. 379. USDA.

Henderickx, H., and J. Martin. 1963. In vitro study of the nitrogen metabolism in the rumen. Comp. Ren. Researches Sci. Ind. Agr., Bruxelles. 21:11.

Hymowitz, T., J.W. Dudley, F.I. Collins, and C.M. Brown. 1974. Estimation of protein and oil concentration in corn, soybean, and oat secd by near-infrared reflectance. Crop Sci. 14:713.

Lehninger, A.L. 1970. Protein purification and characterization. Biochemstry. Worth Publishers, New York.

Little, C.O., W. Burroughs, and W. Woods. 1963. Nutritional significance of soluble nitrogen in dietary proteins for ruminants. J. Animal Sci. 22:358.

McClure, W.F., K.H. Norris, and W.W. Weeks. 1976. Rapid spectrophotometric analysis and the chemical composition of tobacco. Part 1: Total reducing sugars. Beitrage Zur Tabokforschung (In Press).

Norris, K.H., R.F. Barnes, J.E. Moor, and J.S. Shenk. 1976. Predicting forage quality by infrared reflectance spectroscopy. J. Animal Sci. 43:889.

Norris, K.H., and J.R. Hart. 1965. Direct spectrophotometric determination of moisture content of grains and seeds. Proc. 1963. Intl. Symp. on Humidity and Moisture. Principles and methods of measuring moisture in liquids and solids. Humidity and Moisture. 4:19.

Rinne, R.W., S. Gibson, J. Bradley, R. Seif, and C.A. Brim. 1975. Soybean protein and oil percentages determined by infrared analysis. Agr. Res. Pub. ARS-NC-26, USDA.

Shenk, J.S., K.H. Norris, and R.F. Barnes. 1977. Forage and feedstuff analysis with infrared reflectance spectro/computer system. 13th Intl. Grassl. Congr. Leipzig. German Democratic Republic. Section 10:455.

Shenk, J.S., M.O. Westerhaus, and M.R. Hoover. 1979. Analysis of forages by infrared reflectance. J. Dairy Sci. 62:807-812.

Sullivan, J.T. 1964. Chemical composition of forages in relation to digestibility by ruminants. Agr. Res. Service. A77. 16:34-62. USDA. Washington, D.C.

Sullivan, J.T. 1969. The chemistry of silage fermentation. In: Chemical composition of forages with reference to the need so the grazing animals. Agr. Res. Service Bull. No. 34-107. USDA.

Van Soest, P.J. 1963. Use of detergent in the analysis of fibrous feeds. II. A rapid method for the determination of fiber and lignin. J. AOAC. 46:829.

Van Soest, P.J., and W.C. Marcus. 1964. Method for the determination of cell wall constituents in forages using detergent and the relationship between this fraction and voluntary intake and digestibility. J. Dairy Sci. 47:704.

Van Soest, P.J., and R.H. Wine. 1967. Use of detergent in the analysis of fibrous feeds. IV. The determination of plant cell was constituents. J. AOAC. 50:50

CHANGE OF ADDRESS notices should be sent to the Managing Editor, 2760 West Fifth Ave., Denver, Colo. 80204, no later than the first day of the month of issue. Copies lost due to change of address cannot be replaced unless adequate notice is given. To assure uninterrupted service, provide your local postmaster with a Change of Address Order (POD Form 3575) indicating thereon to guarantee forwarding postage for second-class mail. 